\title{
Corporate Social Responsibility and Sustainable Development
}

\author{
Emilia G. Arthus ${ }^{1}$, Mercedes T. Alvarez ${ }^{2}$
}

\begin{abstract}
:
Corporate social responsibility (CSR) meaning the active and voluntary contribution of firms to enhance welfare, is achieving a greater importance in Business administration as an intangible asset which management generates competitive advantages and promotes sustainable development. This work indentifies similarities between CSR management and Intellectual Capital management, this one meant as those activities which help us to manage the knowledge of the firm. Our aim is that firms understand the importance of considering CSR as a corporate strategy that enhances the value of the organization, and that they become conscious about its efficiency and efficacy.
\end{abstract}

\section{Key Words:}

Corporate Social Responsibility, Social Innovation and Business Development

JEL Classification:

\footnotetext{
${ }^{1}$ Department of Financial Economics and Accountancy, University of La Coruna, Spain, e-mail:egar@udc.es

${ }^{2}$ Department of Financial Economics and Business Administration, University of La Coruna, Spain, e-mail: mercedes.teijeiro@udc.es
} 


\section{Introduction}

Since the middle 70s we have been living in a world financial globalization that as time went by has extended to the whole aspects of capital accrual and competitiveness. Such globalization has generated, and continues doing it, some worldwide changes, and knowledge has become a main element for the firm. We currently need to be conscious than an important part of that knowledge is evolved with intangible assets. In order to reach a competitive advantage, firms must rely on the suitable professional abilities of their staff, their attitude and diligence; firms need to implement innovation processes permanently up to date, customers fidelity, a good relation with their staff, a suitable organizational structure, some ability to gain and keep longer the best professionals, etc. The whole of these terms is commonly named Intellectual Capital and most of related research agrees with that concept involves three dimensions: human capital, structural capital and relational capital (Edvinson \& Malone, 1997; Bontis et al., 2000; Havlíček, Břečková and Zampeta, 2013).

Additionally, Corporate Social Responsibility (CSR) as the active and voluntary contribution to the social, economic and environmental improvement performed by the firms is taking more and more significance in Business administration since it has become an intangible asset whose management generates competitive advantages and promotes sustainable development (Thalassinos and Zampeta, 2012).

The aim of this paper is the study of the improvement reached in Intellectual Capital when firms take better actions in CSR. To evolve this paper we have identify some coincidences between Intellectual Capital Management and CSR Management, in the meaning that they are activities that help us to manage our firm knowledge. Our final purpose meets with the fact that firms understand the important about considering CSR as a corporate strategy and the fact of being conscious about its efficiency and efficacy.

\section{Corporate Social Responsibility (CSR)}

Among other elements, a firm consists of a set of persons that are arranged in order to achieve a goal, an economic goal. The achievement of that purpose involves managing human, material and organizational resources that affect the social environment in a positive or a negative way. That group of people interface in their own social environment, both as people joined that interact in their society, and as an individual element of that social system.

We can define CSR as the voluntary commitment of the firms with both social development and preserving environment, right from his social composition and a responsible behaviour with people and all the stakeholders they interact with (AECA, 2004). The main idea underlying CSR is that Business and society are not 
far away from each other, but they are intertwined. Society has some expectations about firm behaviour and about their impact (Wood, 1991). Therefore, those organizations will be the responsible subject about CSR, otherwise, the rest of elements and individuals that are connected with and affected by their performance will be named as stakeholders.

Stakeholders can be classified in base of their relation with the firm, if they are into the organization (internal) or not (external). Moreover, the Conceptual Framework for CSR issued by AECA point out staff and shareholders or owners as internal stakeholders, and customers, suppliers, competitors, social agencies, civil services, society, environment and future generations, as external stakeholders.

Stakeholders are particularly concerned about the requirements they hope to fulfil with the firm performance, or from their relation with the firm. Some requirements are joined for all of them (common requirements), others depend on their particular relation with the firm (specific requirements). We can consider as common requirements of stakeholders:

- Information transparency to improve confidence in the firm.

- Participation and dialogue, to reach a beneficial relation between both parts.

- Mutual benefit made up of considerations that may develop and improve the economic, social and environmental relation in a balanced and sustainable way.

Table 1 reflects specific requirements, that is, in base of the special relation between stakeholders and the firm.

Table 1: Specific Requirements by the Stakeholders

\begin{tabular}{|l|l|}
\hline \multirow{5}{*}{ Staff } & $\begin{array}{l}\text { Fair payback for the task. } \\
\text { Share benefits. } \\
\text { Labour health and welfare. } \\
\text { Respect and professional development. } \\
\text { Training. } \\
\text { Iqual terms and opportunities. } \\
\text { Work-life balance. } \\
\text { Job stability, etc. }\end{array}$ \\
\hline Shareholders & $\begin{array}{l}\text { Get back investment with both profitability and share value } \\
\text { increase. } \\
\text { Fair, transparent and periodical information. } \\
\text { Correct risk Management of environmental and social requirements. } \\
\text { Improve profitability taking advantage of opportunities arisen from } \\
\text { the cooperation with other stakeholders. } \\
\text { Encourage shareholders to an easier and more direct participation, } \\
\text { even the minority ones. } \\
\text { Socially responsible investors express needs beyond the financial } \\
\text { aspects. }\end{array}$ \\
\hline
\end{tabular}




\begin{tabular}{|l|l|}
\hline Customers & $\begin{array}{l}\text { Consumer training and skills. } \\
\text { Reasonable prizes. } \\
\text { Products quality, safety and reliability. } \\
\text { Responsible and ethical advertising. } \\
\text { Information and custom service before, during and after purchasing. } \\
\text { Eco-friendly production process, respectful with human rights and } \\
\text { fair trade. } \\
\text { Certified performance, products and processes. }\end{array}$ \\
\hline Reliance. \\
Mutual benefit. \\
$\begin{array}{l}\text { Free trade/competition, transparency and fair choice. } \\
\text { Contract compliance. } \\
\text { Reasonable prize, payment and delivery time conditions. } \\
\text { Quality. } \\
\text { Cooperate to invest in constant improvement. }\end{array}$ \\
\hline Competitors & $\begin{array}{l}\text { Trusty behaviour. } \\
\text { Strategic alliances and industry associations to collaborate with. }\end{array}$ \\
\hline Social agents & $\begin{array}{l}\text { Information availability. } \\
\text { Consultation ability and influence. }\end{array}$ \\
\hline Civil service & $\begin{array}{l}\text { Watch over duty compliance in an imperative or cooperative way in } \\
\text { relation to the three aspects of development: economic, social and } \\
\text { environmental. }\end{array}$ \\
\hline $\begin{array}{l}\text { Ligilance and information about nearby performance, so they can } \\
\text { not be a threat for humans or environment. } \\
\text { Commitment with progress and local development. } \\
\text { Knowledge contribution to improve welfare. }\end{array}$ \\
\hline $\begin{array}{l}\text { Society and } \\
\text { general public }\end{array}$ & $\begin{array}{l}\text { Worthy behaviour. } \\
\text { Economic, social and environmental positive contribution. } \\
\text { International law and good practice observation. }\end{array}$ \\
\hline $\begin{array}{l}\text { Environment } \\
\text { and future } \\
\text { generations }\end{array}$ & $\begin{array}{l}\text { Harmony with the environment. } \\
\text { Preserve resources. }\end{array}$ \\
\hline
\end{tabular}

Source: Own elaboration

The strategic implementation of stakeholders and their requirements is necessary to achieve business and social responsibility aims. The firm must be seen as a shared project that supposes the achievement of its strategic objectives, the active participation and the satisfaction of stakeholders' requirements.

\section{Corporate Social Responsibility as a Corporate Strategy}

The aim of CSR consists in providing management elements to innovate and improve the firms' impact, in such a way that they could generate socially responsible outcomes (AECA, 2004).

Both in business and academic field, CSR has been a transverse subject of research ${ }^{3}$. This transverse approach has lead to different interpretations and great theoretical

\footnotetext{
${ }^{3}$ More information in the 2005 Economist Intelligence Unit (EIU) Report "The importance or Corporate Responsibility" where a great number of initiatives developed is shown.
} 
bodies (Garriga and Melé, 2004) as instrumental, politic, integrative or ethical theories.

With regard to instrumental theories, we can find works that demonstrate how the implementation of some CSR tools can have a positive effect in economic and financial results (Margolis and Walsh, 2008, Orlitzky et al, 2003), but if we focus on its relation with financial profitability (Burke and Logsdon, 1996) we cannot meaningfully conclude anything like that, because there are studies with a positive relation and another ones without relation or with a negative one (Toro, 2006). The reason of such a lack of significativity lies not only in the broad range of CSR definitions and its hard assessment, but in the lack of information resources availability about CSR behaviour, the limited number of firms we can examine does not allow reliable studies. This shortage of empirical evidences, combined with the heterogeneous information resources, have made most of the managers interpret it as an expense instead of as an investment (EIU, 2005). It seems like firms perceived as unavoidable the rules that protect the labour rights and that contribute to preserve the environment (Ruíz, 2007).

At last, the focus on a direct correlation between CSR and short term profitability becomes a broader meaning which is in relation with the study about CSR management as a firm strategic activity that leads to long term competitive advantages and that will be a firm value cause (this is the integrative policy version). However, new research is focusing to know the underlying conditions cause CSR is able to help organizations developing competitive advantages, in the mean of the firm as a whole whose purpose is not only the owners benefit also the satisfaction of stakeholders requirements, these ones are those individuals or agents (environment, future generations, etc.) affected in any way by the firm or its performance, whit a legitimate and direct or indirect interest in its operation, and at the same time could influence the objectives and survival of the firm (AECA, 2004).

The core of this idea is that firm will have a long term growing if and only if its processes and products match some ethical standards in its management, and also responds the stakeholders' requirements (De la Cuesta et al. 2002). When the firm operates with a responsible behaviour in the search of stakeholders' requirements generates more confidence and reduces the risk related with opportunist behaviour of those groups due to information asymmetry. That bad behaviour can damage firm purpose or results. At last an intangible capital arises, and its feature has a great strategic value (Sandulli, 2008; Fombrun, Gardberg y Barnett, 2000). 
Table 2: Internal Behaviour Socially Responsible

\begin{tabular}{|c|c|}
\hline With staff & $\begin{array}{l}\text { Training and learning at any level. } \\
\text { Delegation and team working to encourage a better performance. } \\
\text { Transparency and communication between levels. } \\
\text { Flexible and reasonable hours with the aim of a work-life balance. } \\
\text { Staff diversity with a presence of several ethnic and social groups: young } \\
\text { and aged people, men and women, handicapped persons, etc. } \\
\text { Coherent and transparent payback policy. } \\
\text { Equal opportunities and responsible selection trials and hiring. } \\
\text { Share benefits and shares to enhance their commitment with the } \\
\text { management and firm work. } \\
\text { Job stability to reach professional and human development. } \\
\text { Working health and welfare as a main condition, with a compliance } \\
\text { extended beyond legality. } \\
\text { Responsibility with all stakeholders when the firm is immersed in a } \\
\text { reconversion plan. }\end{array}$ \\
\hline $\begin{array}{l}\text { With } \\
\text { shareholders } \\
\text { and } \\
\text { proprietors }\end{array}$ & $\begin{array}{l}\text { Get back investment with share value increase and a realistic and } \\
\text { reasonable dividend policy. } \\
\text { Transparent management and results information, without trick } \\
\text { accountancy that shape the true and fair view of the firm. } \\
\text { Socially responsible investments. }\end{array}$ \\
\hline $\begin{array}{l}\text { Production } \\
\text { process } \\
\text { management }\end{array}$ & $\begin{array}{l}\text { Cut the use of not renewable natural resources to eliminate waste. } \\
\text { Reduce the negative environmental effects. }\end{array}$ \\
\hline $\begin{array}{l}\text { Customers, } \\
\text { suppliers and } \\
\text { competitors }\end{array}$ & $\begin{array}{l}\text { Quality and reliable products and services at reasonable prices. } \\
\text { Transparent, fair and responsible selection of suppliers and commercial } \\
\text { cooperation in base of mutual benefit. } \\
\text { Collaboration and strategic partnership with competitors, whenever this } \\
\text { not be detrimental to interested third parts. }\end{array}$ \\
\hline $\begin{array}{l}\text { Local } \\
\text { community }\end{array}$ & $\begin{array}{l}\text { Job, tax income and talent and wealth attraction. } \\
\text { Preserve environment. } \\
\text { Collaboration with community projects (welfare). }\end{array}$ \\
\hline $\begin{array}{l}\text { With society } \\
\text { as a whole }\end{array}$ & $\begin{array}{l}\text { Direct collaboration with international organizations that promote } \\
\text { Corporate social responsibility. } \\
\text { Promote CSR from international business networks, especially about } \\
\text { subjects as human rights and environment preservation. }\end{array}$ \\
\hline
\end{tabular}

Source: Own elaboration

The narrow vision to implement CSR just to avoid negative consequences has to be broadened to a new vision that also includes the positive effects that its management will return not only to the firm, but to the society as a whole. The message we have tried to express through this section is that being involved with social responsibility is more related to the achievement of a strategic aim and to long term success than to altruism or morals (Fernández and Martínez, 2008; Guerras and López, 2003). This 
is the purpose of the next section: the demonstration of the relation between CSR and IC management and their implications.

\section{Corporate Social Responsibility Management with Regard of the Theory of Intellectual Capital Field}

Once the foundations we needed to support our paper are laid, we will focus on the aim, that is, to demonstrate how the IC management is influenced by CSR. IC is the accrual value of the organization knowledge available for any activity range, a concept that includes own knowledge, applied experience, organizational technology, customer relations and all the professional skills meaning a market competitive advantage for the firm. The key to manage IC is leading its conversion from knowledge (raw material) into something valuable for the organization, so that IC sources when the knowledge (isolated or organizational) is used and shared to create organizational value. We must not forget that the whole, as in this case, is always greater than the sum of its parts.

The classification of IC that has reached the greater consensus is that which considers IC divided in three parts, three capitals that are Human Capital, Structural Capital and Relational Capital. Human Capital means the knowledge that lies in the staff and lets the company create value and competitive advantages. This capital lies on the persons who work in the organization, and have technical and technological skills and training, motivation, that take part, etc. Relational Capital means the corporate value of the relations held with the environment (from suppliers, customers, civil services, consumer associations, social agents, etc.). Relational Capital comes from wherever on the outside than can create added value.

Structural Capital includes all the knowledge that may be taken by the firm and then remains available, either as a part of its structure or processes, or being a part of its culture. We can consider included any bit of structured knowledge what internal efficiency and efficacy can depend on, as organizational routines, management systems, process guidelines and databases or the available technology, among others.

Traditionally management models have been exclusively focused on tangible assets, those that are included in the general ledger, but they are not able to reflect the value of intangible assets. Nevertheless, since last decades of C20, management models attached importance to assess intangible resources as Human Capital, knowledge and IC as a whole, with the intention of manage them in a suitable way. The new competition methods, especially those based on uniqueness lay basically on intangible resources. So, IC has become a source of competitive advantage whose suitable management could both create and keep that advantage (Bueno, 2005).

As we generally know, a good and efficient management of any capital essentially needs suitable information and of course an assessment method that allows we can 
control and monitoring the effort made. Obtaining the information we need when we talk about CSR is difficult since lots of CSR behaviour are involved, and from quite a lot of firms. That behaviour stands out because of their attempt to build intangible items as firm reputation or the confidence placed by stakeholders, so they are very difficult to assess. In despite of, this difficulty has not avoided the rise of any initiatives as Global Reporting Initiative (GRI) that has become a worldwide reference in social responsibility reporting.

GRI focuses its report on the called "triple bottom line" (Elkington, 1997), that is showing the three elements of social responsibility: economic, social and environmental.

Each element is divided into several categories and aspects which help users understand what any performance indicator means measuring each one of them. The relevance of these indicators lies in the transformation of firm behaviour, in order to change their strategies with the aim of match the most indicators that is possible.

Intellectual Capital (IC), unlike GRI guide which is broadly used in business ${ }^{4}$, has not reached a consensus with the indicators that may be included in a guide, neither at domestic nor at international level. This lack of a specific and generally accepted report does not mean that there are not any similarities between CSR and IC management, so we can state that investing in CSR attitudes also means investing in IC outcome, because CSR supports knowledge management in the organization, although it is not the only tool available to manage IC (see Figure 1).

Figure 1: Socially Responsible Behaviour that is Available for IC Management

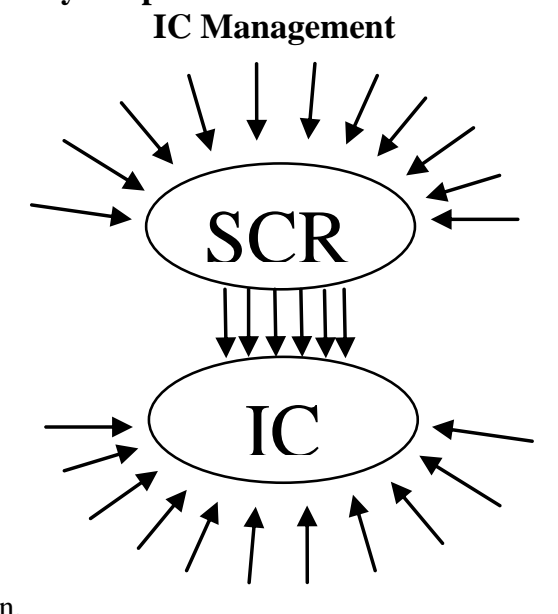

Source: Own elaboration.

\footnotetext{
${ }^{4}$ An KPMG report dated in 2005 certifies that more than $40 \%$ of the analyzed firms declare that they followed the GRI guidelines when they prepared their social reports.
} 
If we address on CSR report and internal behaviour considered as socially responsible, we can observe that many aspects included in the sustainability report are nearly related to IC.

Table 3 shows that socially responsible behaviour that has influence on IC, and more specifically if they support Human Capital, Structural Capital or Relational Capital.

Table 3: Internal behaviour socially responsible that has influence on Intellectual Capital

\begin{tabular}{|c|c|}
\hline SOCIALLY RESPONSIBLE BEHAVIOUR & $\begin{array}{l}\text { INTELLECTUA } \\
\text { L CAPITAL }\end{array}$ \\
\hline $\begin{array}{l}\text { Training and learning at any level. } \\
\text { Offer to the staff continuous learning opportunities. } \\
\text { Draw up a plan for and manage their professional career. } \\
\text { Delegation and team work to encourage individuals in their performance. } \\
\text { Involve staff with the business project. } \\
\text { Transparency and communication between levels. } \\
\text { Team work and innovation rewarding. } \\
\text { Flexible and reasonable hours with the aim of a work-life balance. } \\
\text { Staff diversity with a presence of several ethnic and social groups: young } \\
\text { and aged people, men and women, handicapped persons, etc. } \\
\text { Linguistic normalization. } \\
\text { Coherent and transparent payback policy. } \\
\text { Equal opportunities and responsible selection trials and hiring. } \\
\text { Share benefits and shares to enhance their commitment with the } \\
\text { management and firm work. } \\
\text { Job stability to reach professional and human development. } \\
\text { Working health and welfare as a main condition, with a compliance } \\
\text { extended beyond legality. } \\
\text { Responsibility with all stakeholders when the firm is immersed in a } \\
\text { reconversion plan. }\end{array}$ & Human Capital \\
\hline $\begin{array}{l}\text { Get back investment with share value increase and a realistic and } \\
\text { reasonable dividend policy. } \\
\text { Promote participatory management systems to allow associates to work } \\
\text { with autonomy. } \\
\text { Favour a good work climate that reject conveniently accepted behaviour } \\
\text { and habits and so drive a general taking on responsibility. } \\
\text { Voluntary formation of interfunctional and interdepartmental working } \\
\text { teams. } \\
\text { Implement information and communication technologies that allow save, } \\
\text { process and set up data and information, and improve internal and } \\
\text { external communications. } \\
\text { Transparent management and results information, without trick } \\
\text { accountancy that shape the true and fair view of the firm. } \\
\text { Encourage organizational culture that considers changing as something } \\
\text { natural and necessary, open-minded and involved with innovation } \\
\text { management and knowledge development. } \\
\text { Encourage ethics as a part of corporate culture. } \\
\text { Socially responsible investments. } \\
\text { Cut the use of not renewable natural resources to eliminate waste. } \\
\text { Reduction of environmental negative impact. }\end{array}$ & $\begin{array}{c}\text { Structural } \\
\text { Capital }\end{array}$ \\
\hline
\end{tabular}




\begin{tabular}{|c|c|}
\hline $\begin{array}{l}\text { Quality and reliable products and services at reasonable prices. } \\
\text { Elaborate customers satisfaction reports that take into account the } \\
\text { perception on firm's efficiency, arisen from the knowledge of own needs } \\
\text { and its response ability. } \\
\text { Transparent, fair and responsible selection of suppliers and commercial } \\
\text { cooperation in base of a mutual benefit. } \\
\text { Collaboration and strategic partnership with competitors, whenever this } \\
\text { not be detrimental to interested third parts. } \\
\text { Interact with civil service, towards employment policy, tax income, etc. } \\
\text { and collaborate with public management. } \\
\text { Develop and keep thru time collaboration alliances or agreements with } \\
\text { other organizations or institutions. } \\
\text { Collaboration with community projects (welfare). } \\
\text { Preserve environment. } \\
\text { Direct collaboration with international organizations that promote } \\
\text { Corporate social responsibility. } \\
\text { Promote CSR with international business networks, especially about } \\
\text { issues as human rights and environment preservation. } \\
\text { Set fluent, transparent and solid communication channels with all the } \\
\text { stakeholders (customers, suppliers, allied, competitors, institutions, public } \\
\text { service, mass media). } \\
\text { Rigorous and truthful information about all the product features and the } \\
\text { possible negative consequences from their use, as well as to assume the } \\
\text { responsibility of the negative effects that could be caused. } \\
\text { Keep ethics with advertising, respecting any possible consumer, taking a fair } \\
\text { competition and respecting people's dignity. }\end{array}$ & $\begin{array}{c}\text { Relational } \\
\text { Capital }\end{array}$ \\
\hline
\end{tabular}

Source: Own elaboration

\section{A Survey through Social Responsibility in Spain}

In this section we will try to present graphically the information collected from the reports available for a sample of 168 firms, both national and international ones, which develop their business activity in Spain. The data have been collected from the report called "Corresponsables: Empresa responsible y sostenible 2008".

At first, we tried to focus on four stakeholders, Staff, Suppliers, Customers and Shareholders, however the information issued by the consulted firms has not offered significant data for Shareholders, so this category was not included.

\subsection{Commitment with staff}

Chart 1 shows the percentages of socially responsible actions related to staff, that the 168 surveyed firms had adopted. The most obvious conclusions we can underlie are that "Training and talent management" and "Work-life balance, telecommuting and family assistance" are the most recurrent policies and those which have implied a greater effort: a $19.21 \%$ of socially responsible actions are related to both training in or out of the firm and encouraging their professional careers, and the aim of $16.32 \%$ is to favour work-life balance, and involve timework reductions, leave, telecommuting and family assistance for minors and disabled. Staff training has always been a major element for firm value, but work-life balance is new and it claims to be a key element for entity survival. 
The tag "Others" include:

- Job stability when the firm is immersed in a reconversion plan.

- Staff commitment with the Strategic plan.

- $100 \%$ payback in case of sick leave.

- Capital shares

- Rational use of not renewable natural resources to eliminate waste.

- Linguistic normalization

- Eradicate child labour

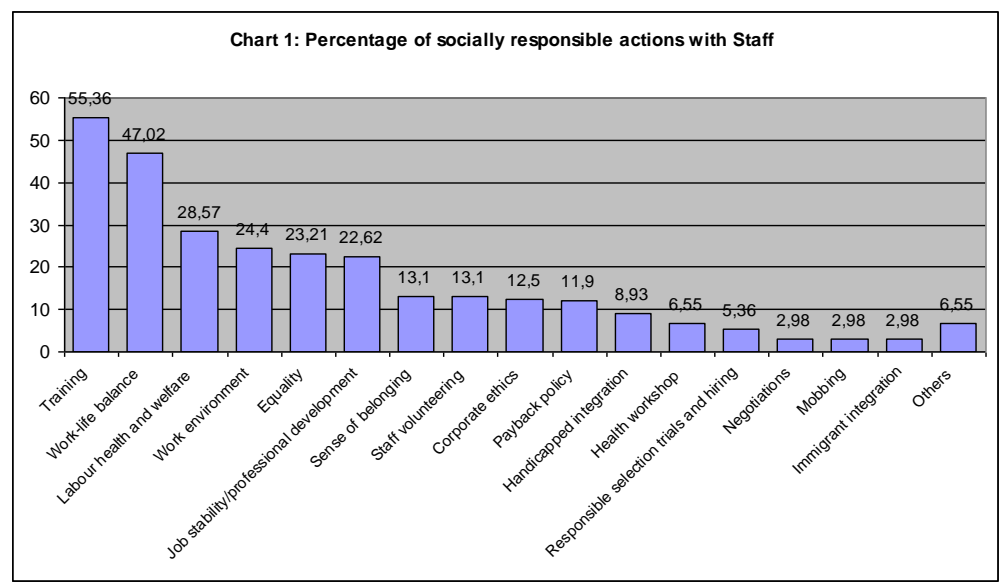

\subsection{Commitment with Customers}

Chart 2 shows the percentages of socially responsible actions related to customers. One of the conclusions we can draw is that we can observe that more than half of them $(52.05 \%)$ are related to customers' attention and to their satisfaction level with the firm product or service, followed by the actions involving product features as quality, reliability and safety $(19.3 \%)$, this is perceptible if we pay attention to those firms that have obtained a quality certification as ISO or similar one $(8.77 \%)$. So we can state that product and process quality stand out with a $28.07 \%$.

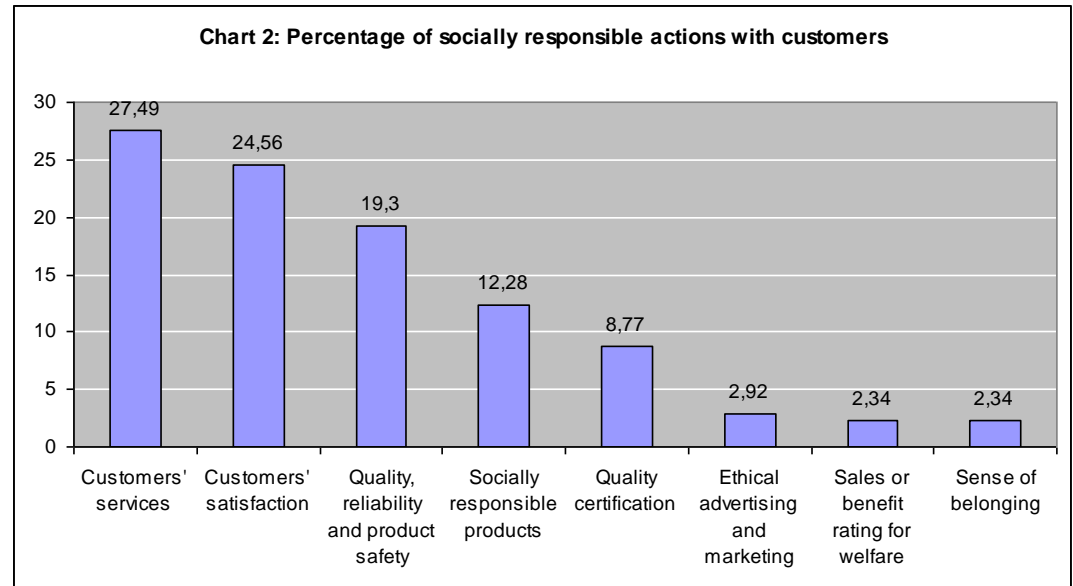




\subsection{Commitment with Suppliers}

Chart 3 shows the percentages of socially responsible actions related to suppliers and it seems clear that firms take a strong interest in integrating their suppliers into their value chain and in involving them in their environmental and human-right respectful policies and with safety. If we consider as the actions directed towards sharing a Code of ethics $(41.33 \%)$ as a whole and those who seek more quality by preserving environment and safety $(29.33 \%)$, the result amounts to $70.66 \%$.

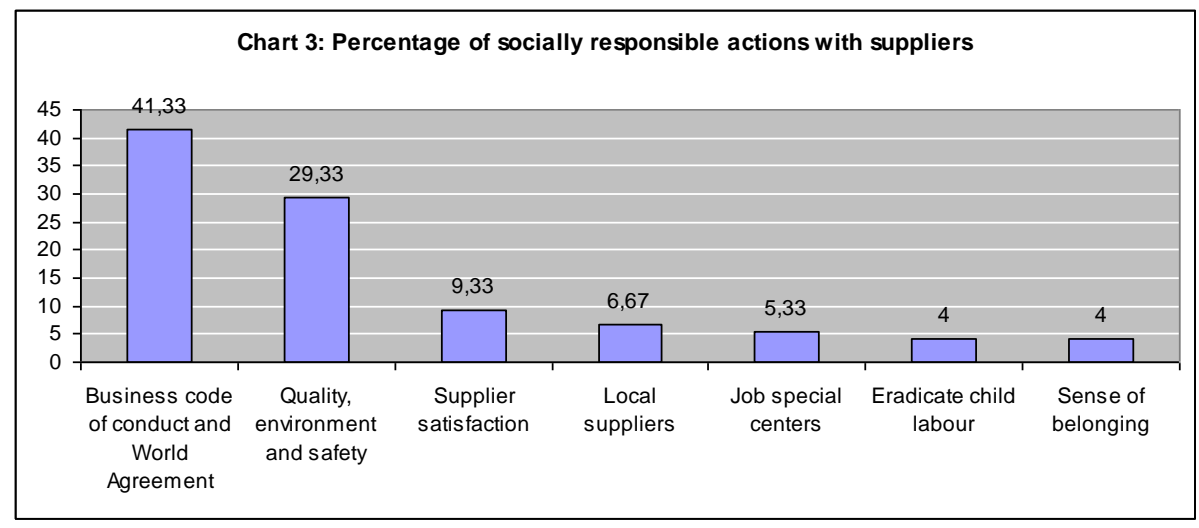

\section{Conclusion}

Firms are more and more conscious about the positive and negative influences of their performance either at environmental or at social scope, but they need have the willpower for integrating them totally in their strategic policy and then communicate them. Any organization has some basic purposes that are value creating, efficiency or improve its competitiveness. The implementation of ethics and CSR in their decisions of strategic management ought not to jeopardize reaching those purposes but to contribute to achieve them (Steiner y Steiner, 2000). CSR must not be implemented only to avoid negative consequences, but also and basically to generate positive effects for either the firms or the society. This has been the main objective underlying this paper, that is to demonstrate that the way the firm manage its CSR has an effect on the relation with the stakeholders: investors, customers, suppliers, staff, communities and government, generating intangible assets than increase the IC of the organizations and their competitive advantages, as can be firm reputation, corporate image, staff commitment and involvement, customers loyalty and faithfulness, the greater collaboration with shareholders and partners and the best ability to establish alliances and cooperation agreements, between others.

Finally, to say that is necessary that economic theories strengthen the analysis of the need to develop ethics into organizations, the economic justification and the advantages that the firm can obtain (Goshal, 2005). On the other side, the firms that lead any industry and have yet an experience with socially responsible behaviour 
should promote with their competitors some joint initiatives, with the purpose of that benchmarking firms in the same industry can become an incentive for integrating CSR in the strategic policy of all of them.

\section{References}

Asociación Española de Contabilidad y Administración de Empresas (AECA) (2004), Marco conceptual de la Responsabilidad Social Corporativa, AECA, Madrid.

Asociación Española de Contabilidad y Administración de Empresas (AECA) (2005), Responsabilidad Social Corporativa. Límites de la información de sostenibilidad: entidad, devengo y materialidad, AECA, Madrid.

Asociación Española de Contabilidad y Administración de Empresas (AECA) (2005), Limites de la información de sostenibilidad: entidad devengo y materialidad, AECA, Madrid.

Bontis, N. (1998), "Intellectual capital: An exploratory study that develops measures and models", Management Decision, 36, pp. 63-76.

Bueno, E. (2005), "Génesis, evolución y concepto del Capital Intelectual: Enfoques y modelos principales", Capital Intelectual, No. 1, pp. 8-19.

Burke, L. and Logsdon, J.M. (1996), "How corporate social responsibility pays off", Long Range Planning, vol. 29, No. 4, pp. 495-502.

De la Cuesta, et al (2002), La responsabilidad social corporativa: una aplicación a España, Madrid, UNED.

Ebner, D. (2007), "Assessing Corporate Social Responsibility: Csr-Scan", available at: www.crrconference.org/downloads/crrc2007ebner2.pdf.

Edvinsson, L. and Malone, M.S. (1997), Intellectual capital. Realizing your company's true value by finding its hidden brainpower, Harper Collins Publishers, Inc.

Economist Intelligence Unit (EIU) (2005), "The importance of Corporate Responsibility", available at: www.oracle.com.

Elkington, J. (1997), Cannibals with Forks: The Triple bottom Line of $21^{\text {st }}$ Century Business, Capston, Oxford.

Fernández, R. and Martínez, A. (2008), "Naturaleza estratégica de la Responsabilidad Social Empresarial”, Revista Globalización, Competitividad y Gobernabilidad, Vol. 2, No. 2, pp. 116-125.

Fombrun, C., Gardberg, N. and Barnett, J. (2000), "Opportunity platforms and safety nets: Corporate citizenship and reputation risk", Business and Society Review, 105, pp. 85106.

Garriga and Melé (2004), "Corporate Social Resonsibility Theories: Mapping the Territory", Journal of business Ethics, 53, pp. 52-71.

Goshal, S. (2005), "Bad management theories are destroying good management practices", Academy of Management Learning and Education, 4 (1), pp. 75-91.

Guadamillas, F. (2008), "La responsabilidad social de la empresa y la gestión de la innovación: una perspectiva estratégica”, Revista de Contabilidad y Tributación CEF, No $35 / 2008$, pp. $137-174$.

Guerras, L. and López-Hermoso, J. (2003), "La responsabilidad social de la empresa. Perspectivas desde la dirección estratégica de la empresa", Revista del Instituto de Estudios Económicos, pp. 263-275. 
Havlíček, K., Břečková, P. and Zampeta, V. (2013), "Quality Management as a Part of CRM”, European Research Studies Journal, Vol. XVI(4), Special Issue in SME's, pp. $15-28$.

Hopkins, M. (2007), Corporate Social Responsibility and International Development. Is Business the solution?, Earthscan, London.

KPMG (2005), International Survey of Corporate Responsability 2005, KPMG, Rotterdam.

Margolis, J. and Walsh, J.P. (2001), People and profits? The search for link between a company's social and financial performance, Lawrence Erlbaum Associates Publisher, Mahwh, New Jersey.

Orlitzky, M., Schmidt, F.L. and Rynes, S.L. (2003), "Corporate Social and Financial Performance", Organization Science, 24, 3, pp. 403-443.

Ruiz Lamas, F. (2007), "La responsabilidad social corporativa, ¿genera valor?", Revista AECA, $\mathrm{n}^{\mathrm{o}} 78$, pp. 3-7.

Sandulli, F. (2008), "Estrategias de filantropía corporativa global: el caso de las empresas españolas en Latinoamérica", Revista Globalización, Competitividad y Gobernabilidad, Vol. 2, No.1, pp. 100-111.

Steiner G.A. and Steiner, J.F. (2000) Business, Gobernment and Society: A Managerial Perspective, McGraw-Hill.

Thalassinos, I.E. and Zampeta, V. (2012) "How Corporate Governance and Globalization Affect the Administrative Structure of the Shipping Industry", Journal of Global Business and Technology, Vol. 8(1), 48-52.

Wood, D. (1991), "Corporate Social Performance Revisited", Academy of Management Review, Vol.4, pp. 691-718. 